\title{
ВИВЧЕННЯ СЕНСИБІЛІЗУЮЧО ДІ НОВОГО РОСЛИННОГО ЗАСОБУ КАПСУЛ «ФІТОВЕНОЛ»
}

\author{
Вінницький національний медичний університет ім. М. І. Пирогова МОз України
}

\begin{abstract}
РЕЗЮМЕ. Хвороби вен залишаються однією з найактуальніших проблем сучасно медицини. Базисом для проведення патогенетично обґрунтовано медикаментозно терапі хронічних захворювань вен $є$ венотонічні лікарські препарати. Поряд з фармакологічною активністю, важливою властивістю нових лікарських засобів $\epsilon$ х нешкідливість, що обумовило вивчення сенсибілізуючих властивостей засобу. Сенсибілізуючу дію досліджуваного засобу оцінювали за його здатністю викликати реакці гіперчутливості сповільненого та негайного типів у тестах кон'юнктивально проби та непрямо дегрануляці мастоцитів.

КЛЮЧОВІ СЛОВА: «Фітовенол», хвороби вен, сенсибілізуюча дія.
\end{abstract}

Вступ. Хвороби вен залишаються однією з найактуальніших невирішених проблем сучасно медицини. За даними статистичних досліджень, поширеність ціє патологі сягає близько $50 \%$ серед осіб працездатного віку та у старших вікових групах збільшується до 90 \% [1, 2, 3, 4]. Базисом для проведення патогенетично обґрунтовано медикаментозно терапі хронічних захворювань вен $€$ венотонічні лікарські препарати. Це численна гетерогенна група фармакологічних препаратів, які виробляють шляхом переробки рослинно сировини чи хімічного синтезу. Враховуючи тенденцію венозних хвороб до хронізаці та труднощі у виборі препаратів при тяжких порушеннях, адекватну фармакологічну регуляцію патологічного процесу можуть забезпечити препарати, які, поряд з вираженим фармакологічним ефектом, не матимуть негативного впливу при тривалому вживанні.

Цим вимогам найбільше відповідають фітопрепарати, важливими особливостями яких $\epsilon$ широкий діапазон терапевтичних доз, здатність активно впливати на уражені мембрано-клітинні структури і метаболічні процеси, висока біодоступність, м'яка дія на організм та фізіологічна корекція порушених функцій, а також легка переносимість.

Тому перспективним було створення нового венотонічного засобу для лікування та профілактики хронічно венозно недостатності. Розроблений склад нового венотонічного засобу капсул «Фітовенол» на основі 7 лікарських рослин. До складу були введені плоди гіркокаштану, листя гамамелісу віргінського, плоди вівса посівного, плоди софори японсько, трава золотушника звичайного, трава гадючника в'язолистого, трава буркуну лікарського.

У попередніх дослідженнях було встановлено, що капсули “Фітовенол" в дозі $150 \mathrm{Mг/Кг} \mathrm{виявля-}$ ють венотонічну, ангіопротекторну, антитромботичну, мембраностабілізувальну, антиоксидантну, протизапальну та гіполіпідемічну ді $[5,6,7,8]$. Поряд $з$ фармакологічною активністю, важливою властивістю нових лікарських засобів $€$ х не- шкідливість, що обумовило вивчення сенсибілізуючих властивостей засобу.

Мета дослідження. Вивчення здатності капсул “Фітовенол» викликати сенсибілізацію організму.

Матеріали і методи дослідження. Сенсибілізуючу дію досліджуваного засобу оцінювали за його здатністю викликати реакці гіперчутливості сповільненого та негайного типів у тестах кон'юнктивально проби та непрямо дегрануляці мастоцитів [9].

Вивчення сенсибілізуючих властивостей капсул «Фітовенол» в тесті «кон'юнктивальна проба» проведено на 12 мурчаках масою тіла 250-300 г. Капсули "Фітовенол" вводили в умовнотерапевтичній дозі $150 \mathrm{мг/кг} \mathrm{та} \mathrm{в} \mathrm{дозі,} \mathrm{яка} \mathrm{в} 10$ разів перевищує - 1500 мг/кг, шляхом внутрішньошлункового введення протягом 14 діб. На 21-у добу після початку сенсибілізаці всім тваринам під верхню повіку закапували одну краплю розчину вмісту капсул "Фітовенол", в концентраці, яка не викликає подразнювально ді на слизову оболонку ока. Ліве око брали за контроль, аналогічно вводячи одну краплю води.

Реакцію слизово оболонки реєстрували через 15 хвилин, 24 години після закапування завершально дози та виражали в балах за наступною шкалою: 1 - легке почервоніння слізно протоки; 2 - почервоніння слізно протоки та склери в напрямку до рогівки; 3 - почервоніння всіє кон'юнктиви та склери.

Для постановки тесту непрямо дегрануляці мастоцитів використовували 24 білих безпородних щури масою тіла 200-225 г. Капсули “Фітовенол" вводили в умовнотерапевтичній дозі $150 \mathrm{мг/кг} \mathrm{та}$ в дозі, яка в 10 разів перевищує $1500 \mathrm{mг/кг,}$ шляхом внутрішньошлункового введення протягом 14 діб.

Для сенсибілізаці тварин дослідних груп застосовували водну суспензію вмісту капсули досліджуваного засобу, а в реакціях in vitro використовували розчин тест-зразка та серію його двора- 
Оеляди літератури, оригінальні дослідження, поеляд на проблему

зових розведень у фізіологічному розчині натрію хлориду.

Для проведення експерименту використовували контрольну групу тварин, яким вводили фізіологічний розчин.

На 21 добу усіх тварин знеживлювали під ефірним наркозом, одержували сироватку для постановки тесту. У попередніх експериментах підбирали концентрацію вмісту капсул, що викликає не більше $10 \%$ неспецифічно дегрануляці. Препарати готували на предметних скельцях, пофарбованих 0,3\% спиртовим розчином нейтрального червоного. До 0,03 мл мастоцитів, отриманих з перитонеального ексудату інтактних тварин, додавали 0,03 мл сироватки піддослідно (сенсибілізовано ) або контрольно групи тварин і 0,03 мл розчину досліджуваного суспезі вмісту капсул. При постановці реакці враховували наступні контролі: 1. 0,03 мл суспензі мастоцитів, 0,03 мл досліджуваних сироваток і 0,03 мл фіз. розчину; 2. 0,03 мл суспензі мастоцитів і 0,03 мл фіз. розчину. Потім препарати інкубували 15 хвилин при $37^{\circ} \mathrm{C}$ та досліджували під світловим мікроскопом. У кожній камері підраховували по 100 клітин. Оцінку результатів проводили, підраховуючи відсоток дегранульованих мастоцитів.

Реакцію вважали позитивною, якщо кількість дегранульованих клітин перевищує $10 \%$ Ступінь сенсибілізуючо ді досліджуваного препрату визначали за шкалою: слабка - від 10 до 20 \% дегранульованих клітин; позитивна - від 20 до $30 \%$ дегранульованих клітин; різко позитивна від $30 \%$ і більше дегранульованих клітин.

Результати й обговорення. У тесті «Кон'юнктивальна проба» введення мурчакам капсул “Фітовенол» впродовж 14 днів не змінювало загальний стан тварин. Проведене на 21 добу тестування показало відсутність проявів будь-яко алергічно реакці у відповідь на закапування завершально дози. У всіх дослідних тварин не спостерігали алергійно запально реакці слизово оболонки ока (табл. 1).

Таблиця 1. Вивчення сенсибілізуючих властивостей капсул «Фітовенол» в тесті «Кон'юнктивальна проба» у мурчаків

\begin{tabular}{|c|c|c|c|c|c|}
\hline \multirow{2}{*}{\multicolumn{2}{|c|}{ Групи тварин }} & \multirow{2}{*}{ Доза, мг/кг } & \multirow{2}{*}{$\mathrm{n}$} & \multicolumn{2}{|c|}{ Офтальмореакція, бали } \\
\hline & & & & 15 хвилин & 24 години \\
\hline \multirow{4}{*}{$\begin{array}{l}\text { Капсули } \\
\text { «ітовнол» }\end{array}$} & контрольне око & \multirow{2}{*}{150} & \multirow{2}{*}{6} & $0(0-0)$ & $0(0-0)$ \\
\hline & дослідне око & & & $0(0-0)$ & $0(0-0)$ \\
\hline & контрольне око & \multirow{2}{*}{1500} & \multirow{2}{*}{6} & $0(0-0)$ & $0(0-0)$ \\
\hline & дослідне око & & & $0(0-0)$ & $0(0-0)$ \\
\hline
\end{tabular}

Отримані результати, дають змогу зробити висновок, що капсули «Фітовенол» в дозах 150 та 1500 мг/кг не виявляють сенсибілізуючо ді в тесті «кон'юнктивальна проба».

у тесті реакці непрямо дегрануляці мастоцитів кількість дегранульованих мастоцитів в сироватці щурів, сенсибілізованих протягом 14 днів досліджуваним засобом відповідала кількості дегранульованих мастоцитів у щурів контрольно групи (табл. 2).

Як видно з таблиці, капсули «Фітовенол» не викликають збільшення рівня в крові гомоцитотропних антитіл і, отже, не виявляють сенсибілізуючо ді.

Таблиця 2. Вплив капсул «Фітовенол» на дегрануляцію мастоцитів у щурів ( $\overline{\mathrm{X}} \pm \mathrm{SX})$

\begin{tabular}{|c|c|c|c|c|}
\hline Групи тварин & $\begin{array}{c}\text { Доза, } \\
\text { мг/кг }\end{array}$ & Шлях сенсибілізації & $\mathrm{n}$ & $\begin{array}{c}\text { Кількість } \\
\text { дегранульованих } \\
\text { мастоцитів, \% }\end{array}$ \\
\hline Інтактний контроль & - & - & 8 & $6,75 \pm 1,18$ \\
\hline Капсули «Фітовенол» & 150 & Внутрішньошлунковий & 8 & $5,13 \pm 0,74$ \\
\hline Капсули «Фітовенол» & 1500 & Внутрішньошлунковий & 8 & $7,00 \pm 0,60$ \\
\hline
\end{tabular}

Аналіз отриманих результатів свідчить про відсутність сенсибілізуючих властивостей у капсул «Фітовенол» в тесті in vitro - реакці непрямо дегрануляці мастоцитів.

Висновки. На підставі вищенаведених даних можна стверджувати, що капсули «Фітовенол» при внутрішньошлунковому введенні в дозі 150 та 1500 мг/кг не виявляють здатність викликати реак- ці гіперчутливості сповільненого та негайного типів у тестах кон'юнктивально проби та непрямо дегрануляці мастоцитів.

Таким чином, капсули «Фітовенол» можна рекомендувати для виробництва як новий венотонізуючий лікарський засіб, який не має антигенних властивостей. 
Оеляди літератури, ориеінальні дослідження, поеляд на проблему

\section{ЛІТЕРАТУРА}

1. Аверьянов М. Ю. Хронические заболевания вен нижних конечностей: учебн. пособ / М. Ю. Аверьянов, С. Г. Измайлов, Г. А. Измайлов. - Новгород : ФГУИПП "Нижполиграф", 2002. - 128 с

2. Алешинская Э. Е. Влияние каштана конского на организм / Э. Е. Алешинская // Фармакол. и токсикол. 1962. - № 4. - С. 455.

3. Антитромботические игемостатические средства // Фармакотерапия заболеваний сердечно-сосудистой системы : лекции для практикующих врачей. - М., 2002. C. $276-305$

4. Belcaro G. Efficacy of topical treatment with Aescin + Essential Phospholipids Gel in a microcirculatory model of venous insufficiency / G. Belcaro // Angiology. - 2004. Vol. 55, №. 6. - P. 15-18.

5. Дослідження протиатерогенно та ангіопротекторно ді капсул «Венотон» на моделі гіпервітамінозу D / Ю. О. Томашевська, Л. В. Яковлєва, Л. В. Гладкова, І. В. Трутаєв // Клінічна фармація. - 2010. - Т.14, № 4 . - C. $42-46$.
6. Яковлєва Л. В. Протизапальна активність капсул "Фітовенол" на моделях запалення викликаних різними флоготропними агентами / Л. В. Яковлєва, Ю. О. Томашевська, Л.В.Гладкова // Здобутки клінічно та експериментально медицини. - 2011. - №1. - С. 113-117.

7. Вивчення капіляропротекторно ді венотонічного рослинного засобу / Л. В. Гладкова, І. В. Трутаєв, А. О. Сілаєв, Ю.О.Томашевська // Клінічна фармація в Укра ні : матер. VIII Всеукра нсько наук.-практ. конф. за участю міжнар. спеціалістів / Редкол. : В. П. Черних та ін. - Х. : Вид-во НФаУ, 2008. - С. 102.

8. Яковлєва Л. В. Дослідження мембраностабілізувально ді капсул «Фітовенол» на моделі спонтанного гемолізу еритроцитів / Л. В. Яковлєва, Л. В. Гладкова, Ю. О. Томашевська : 4-й Національний конгрес "Людина та ліки Укра ни" : тези доповідей, м. Ки в, 23-25 березня 2011 р. - Ки в, 2011. - С. 134-135.

9.Доклінічне вивчення сенсибілізуючо ді лікар ських засобів: метод. рек. / за ред. Г. М. Бутенко. - К., 2002. $-42 \mathrm{c}$.

\section{STADY OF SENSITISING EFFECT OF THE NEW HERBAL PREPARATION CAPSULES «FITOVENOL»}

\section{CYY. O. Tomashevska}

\section{Vinnytsia State Medical University by M. I. Pyrohov of MPH of Ukraine}

SUMMARY: Venous diseases are one of the most actual problems of the modern medicine. The basis for performing pathogenically-grounded medication therapy of chronic venous diseases is venotonic medicinal products. Besides pharmacological activity, the important characteristic of the new medicinal products is their harmlessness, which has led to studying of sensitising characteristics of the product. Sensitising effect of the analysed product was assessed by its property to cause delayed and immediate hypersensitivity reactions within tests of conjunctival samples and indirect mast cell degranulation. KEY WORDS: «Fitovenol», venous diseases, sensitising effect. 